\title{
Implementation of 2013 Curriculum in Improving Education Quality
}

\author{
Bet Shelvia ${ }^{*}$, Karyono Ibnu Ahmad 2, Mahrita ${ }^{3}$ \\ ${ }^{1}$ Master Program of Education Management, Universitas Lambung Mangkurat, Banjarmasin 70123, \\ Indonesia \\ ${ }^{2}$ Graduate Program of Couseling Guideline, Universitas Lambung Mangkurat, Banjarmasin 70123, \\ Indonesia \\ ${ }^{3}$ Graduate Program of Primary Teacher Education, Universitas Lambung Mangkurat, Banjarmasin 70123, \\ Indonesia
}

Article history:

Submission November 2019

Revised June 2020

Accepted July 2020

*Corresponding author:

E-mail: betshelvia30@gmail.com

\begin{abstract}
Curriculum implementation is an application of concepts in the form of curriculum documents into learning process. This study aims to analyze the implementation of K13, using the qualitative and multi-site study design in State Senior High Schools 4 and 6 of Palangka Raya. Data was collected through interviews, observation, and documentation from principals, curriculum representatives, teachers, and selected students through the purposive sampling technique. Furthermore, data validity was carried out through credibility, transferability, dependability, and confirmability. The results show that both schools (1) have properly implemented K13, although it is not yet effective (2) its training and socialization were provided by the LPMP, supervisors, as well as the Ministry of Education and Culture, (3) its obstacle, include teachers' less optimal ability in utilizing learning tools and infrastructure, (4) principals and curriculum representatives were able to provide solutions tailored to meet the obstacles experienced by schools and teachers to create a pleasant and meaningful classroom atmosphere, and (5) educational quality, seen from the achievements of students and schools is have properly. This research is recommended to enable teachers to create various media and learning resources supported by technological devices and for Principals to assist teachers in developing learning tools.
\end{abstract}

Keywords: Implementation, curriculum, quality improvement

\section{Introduction}

The curriculum concept develops with the development of educational theory and practice. The curriculum serves as a guide for conducting educational activities in schools for related parties, both directly and indirectly, school principals, curriculum representatives, teachers, supervisors, parents, the community and students themselves.

Curriculum is an educational design that summarizes all learning experiences provided for students at school. In a curriculum, philosophy, values, knowledge must be integrated with educational actions (Suhaimi \& Rinawati, 2018).

The implementation of the 2013 curriculum requires education implementers to focus learning on attitudes, skills and knowledge competencies. The curriculum plays a central role in improving the quality of education in Indonesia. Improving the quality of education is a development target in the field of national education and is an integral part of efforts to improve human quality. Various efforts are being made such as the procurement of school facilities and infrastructure, certification of professional abilities of educators.

Some of the changes that occurred in the 2013 Curriculum are as follows 1) standard processes that were initially focused on exploration, elaboration, and confirmation were complemented with observation, inquiry, processing, reasoning, presentation, inferring, 
and devising. 2) Learning activities were conducted in the classroom, school premises, and community environment. Therefore, knowledge was not only impacted by the teacher. 3) Teachings were carried out using samples. 4)Theeducational unit was restructured to be able to execute various plans different aspects of learning, and assessment of the students'results in order to improve the efficiency and effectiveness of the graduates' achievementsand competencies (Hidayat, 2013).

Every curriculum designed needs to reflect the school's vision, mission, and goals. It is also important to innovate, update, and develop the previous curriculum (Andriyani et al., 2018). Successful achievement of educational goals is determined by the basic foundation of learning and the elements involved, which are students, the teachers, interactions between students and tutors, the educational environment, and materials/contents (Salasiah et al., 2018).

The 2013 Curriculum was both competency and character-based with the use of a thematic and conceptual approach. This implementationwas expected to help the students improve independentlyand exhibit proper conduct in their daily behaviors (Mulyasa, 2017).

Several obstacles were experienced by teachers in the State Senior High School 4 of Palangka Raya after the implementation of the 2013 Curriculum. Some teachers mentioned that the 2013 curriculum was quite easy, better, and more effective. However, others revealed that theydid not understand the curriculum while some others lacedthe abilityto use learning resources and the media. Therefore the application in the classroom was not optimal.

The State Senior High School 6 of Palangka Raya located in the Tangkiling area, is the only education institution that implemented the 2013 curriculum, which was carried out in stages. The school is located quite far from the city, and this had an impact on socialization and training. Moreover, the limited facilities and infrastructure also affected the implementation of the curriculum.

The tives of this study is to thoroughly describe and analyze: (1) Implementation of the 2013 Curriculum in State Senior High Schools 4 and 6 of Palangka Raya (2) Supporters Implementation of the 2013 Curriculum (3) Obstacles Implementation of the 2013 Curriculum (4) Solutions to overcome those obstacles and (5) quality of educational seen from the achievements of students and schools.

\section{Material and Methods}

This research was conducted from July to October 2019 in State Senior High Schools 4 and 6 of Palangka Raya, using a descriptive qualitative approach and multi-site design. The respondents or key informants were principals, curriculum representatives, teachers, and selected students from State Senior High Schools 4 and 6 of Palangka Raya.

Research objects include time, place, social and cultural settings. Data were collected from interviews, observations, and documentation. Interviews. Complementary sources were documents in the form of photos, correspondence, or written notes.

Data acquired through a variety of techniques were examined, while data reduction, presentation, and verification were also performed. The validity of the data was checked using credible measures. The acquired data were analyzed using a single case and cross-site analysis. Cross-site data analysis activities can be described as follows:

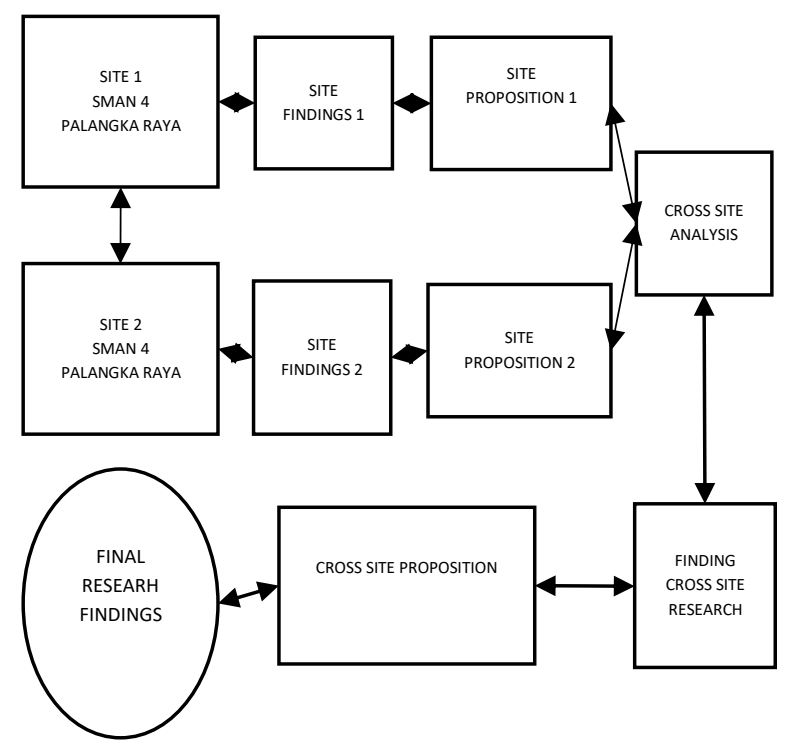

Figure 1: Cross-site data analysis activity 


\section{Results and Discussion}

This chapter discusses the implementation of the 2013 curriculum in improving the quality of educationat State Senior High Schools 4 and 6 of Palangka Raya.

\section{Implementation of the 2013 curriculum}

The findings of the research in these two schools were based on interviews and documentation. The helped the teachers and staff to understand and formulate the needed goals to be achieved through the 2013 curriculum. The implementation of this curriculum was intended to improve school performance in order to effectively and efficiently achieve set objectives.

The Principal plays a huge role in organizing school programs to inculcate character education such as faith and piety, intelligence, achievers in mastering science and technology, competing in the fields of entrepreneurship, health, etc. They are also involved in coordinating the 2013 curriculum for improving the educational quality of schools, division of labor for teachers and staff, guide and develope both the teaching staff and students.

The above activities are similar to State Senior High School 6 of Palangka Raya, where the Principal implements a character education program in accordance with the school's mission, namely performing sports activities, arts and culture, literacy, science activities, and technology. In this context, the mission is a translation of the implementation of character education enforced by State Senior High School 6 of Palangka Raya. The principal helped the teachers and staff to understand and formulate the educational goals that must be achieved through the 2013 curriculum, thereby encouraging the teaching staff to work together in order to achieve set goals.

The duties and roles of principals in realizing this are reflected in the contents of the curriculum programs that were designed and developed. Task Leaders include directing, mobilizing, influencing and empowering (4 M) members. Thus leadership in schools can be interpreted as a person's ability to move, direct, influence and empower the mindset and workings of teachers and school staff to be independent in working (Suhaimi, 2018). Teachers and staff need to perform their respective tasks, which are supervised by the principal who, in turn, reports all activities to the education personnel management to ensure the board of teachers and staff work together to obtain maximum results (Mulyasa, 2013).

The principalguidance in the implementation of the 2013 curriculum was deduced to be good according to the leadership. This was realized when the principalssent teachers to attend the training, which was also actualized throughthe procurement of infrastructureand provision of school facilities. Therefore, for the principal to be able to carry out their duties effectively, good leadership need to be enforced.

The formation of the character will be determined not only on the strength of management in the school organization unit concerned. The power of management depends largely on the quality and strength of the principal as a leader (Suriansyah, 2015).

It was also discovered that the creativity of teachers in State Senior High School shad the learning process conform to the 2013 curriculum, which is character and competence-based. However,results obtainedfrom classroom learning observations proved that the teachers did not display the optimal value of creativity, this is evident in the picture displayed on the LCD slide. Its essence is to aid teachersto display videos, or animations to motivate and bring out the creativity of students during the learning process. In the selection of learning models, the teacher employed various methods tailored to makethe learning process easier for students.

This also occurred in the learning process employed by teachers at State Senior High School 6 in Palangka Raya, it conformedwith the character and competence was based in the 2013 curriculum. However, results obtained from the classroom learning processes showed that the teachers used printed images, with manuals that were not in accordance with the Lesson Plan (RPP). The media used are laptops, LCDs, power points, videos, andimages. 
Conversely, the teacher did not use any of these media according to the RPP reason being that the LCD was widely used for students in classes XI and XII. Furthermore, in the selection of methods/learning models, the teacher employed the lecture method, interactive discussion, and assignments. The learning process employed was quite good, even though the creativity of the teacher remained optimal.

Creativity is a person's ability to create something new either in the form of ideas, aptitude and non-aptitude characteristics, or a combination of existing ideas." Every human being, including teachers, has a creative nature, however, some people are not able to hone their creativity (Suryosubroto, 2010).

In compiling learning tools, teachers are always looking for references from various sources. It is assumed that the use of numerous references makes it easier for teachers to choose the method or strategy that perfectly suits the children's abilities. In the learning design, the teacher uses a characterized plan, with clear learning objectives.

The media is as important as the method employed, which the existing condition. Therefore the creativity of the teacher is critical in the learning process because it is one of the success factors that aid the effectiveness of the teaching and learning processes. When teacher creativity is maximized, students tend to be eager to learn with an increase in its outcome. Creating an active and fun learning environment increases the quality of learning outcomes (Metroyadi, 2017). The other findings in this study, were based on interviews and observations conducted on the Principal of State Senior High School 4 of Palangka Raya and the teachers. It was observed that the students were disciplined by coaching. For example, offering advice, reprimands, and students frequently reminded of school rules. The principal of State Senior High School 6 of Palangka Raya inculcated discipline in students by employing three main methods, namely, awareness, measures, and the teachers acting as role models. Similarly, character education aims to develop cultural values and national character to students, thereby, providing them with the best values (Suriansyah, 2011).
Disciplinary measures that need to be obeyed by students have been stated during the school orientation program to make students understand its rules from the start. The presence of students in a pleasant disciplinary environment causes a positive impact, and rules are not violated. In addition, schools employing student discipline on a daily basis tend to have a positive impact.

Therefore the disciplinary measures employed and the collaboration of students resident in both schools resulted in optimal performance.

The strategy employed in the 2013 curriculum to achieve socialization for students resident in the school premises was through education, workshops, and training.

Socialization is very important in the curriculum as it helps all parties involved in its implementation understand the changes needed to be made in accordance with the main tasks and functions.

Another finding of the two schools in this studywas that some facilities that serve as support to achieve these goals had not been met. Limitations of school facilities were offset by good supervision of the principal, influences the success of teaching and learning processes. The teachers need to make good use of existing learning facilities, and occasionally invite students to explore the environment outside the classroom. Teachers need to develop themselves and pay attention to certain factors that tend to affect the student's achievement, such as the use of learning media. Furthermore, they need to have a pleasant and friendly attitude towards students to make them comfortable in the learning environment.

State Senior High School 4 of Palangka Raya with has an area of 24,676 $\mathrm{m} 2$ and ground floor area of 2,100.5 m2. It consists of an office, a staff room, a science laboratory, a computer laboratory, a health centre, a Mushola, a media/audio visual room of $72 \mathrm{~m} 2$, and a sports facility covering an area of $3519 \mathrm{~m} 2$. In a bid to support school programs in the 2013 curriculum, it has endeavored to provide facilities and infrastructure by budgeting for School Operational Assistance (BOS) funds annually. State Senior High School 6 of Palangka Raya has an area of 27,006 m2. It is 
located on Tjilik Riwut Street, Km 29.5, Tahai Sub-district, Bukit Batu Regency, Palangka Raya City, with concrete markers on the front and the sides by barbed wire and zinc fences. The buildings consist of an office room, a teacher's room, 8 theoretical rooms, a laboratory, a school health center, a mosque, and 2 parking spaces. The permanent school buildings, consists of study, library, offices, and laboratory rooms. However, for proper future development, it is necessary to have a building arrangement and a master or building rehabilitation plan that meets the ideal standards. The number of new classrooms (RKB) also needs to be included to meet the population requirements of the students. The computer, language, Mathematics and Natural Sciences laboratories (physics, chemistry, biology), have acquired the procurement of tools and materials needed by the teachers and students in the last few years.

To improve the quality of teaching, sufficient resources and tools are needed to enable students to study individually (Nasution, 2014). Therefore, the existence of a complete learning facility makes students eager to learn without relying on friends. Schools tend to have good quality or standardassuming the implementation of learning activities is not only supported by the potential of students, the ability of teachers to teach or by the school environment, but also needs to be supported by adequate facilities. Learning facilities are classified into 3 , namely (1) consumable and durable, (2)movable and immovable, (3) Relationships in the learning process (learning tools, teaching aids, and learning media). To assess a school as having standard learning facilities, it must consist of the following (1) Classroom, (2) Library Room, (3) Science Laboratory, (4) Principal Room, (5) Teacher's Room, (6) Places of Worship, (7) School Health centre, (8) toilets (9) Warehouses, (10) playground (Arifin, \& Banawi, 2012).

Although, the facilities and learning resources are inadequate, principals and teachers need to be able to create their own learning tools and also take the initiative to utilize the environment around the school.
Other discoveries from the analysis of the two schools showed that the school environmentsneed to be made conducive for academic studies by creating a safe and orderly atmosphere. The teacher ismostly responsible for creating a conducive learning environment.

State Senior High School 6 of Palangka Raya cultivates 5S, Salam (greetings), Sapa (hollo), Senyum (smiles), Sopan (polite), Santun (genteel). Learning strategies and methods were used to determine whether or not the atmosphere was conducive enough for learning.

The learning environment plays an important role in the formation of an effective school. For two decades, the learning environment in schools was considered as one of the determinants of the effectiveness of a school. Therefore the teacher's role is to get familiar with the responsibilities or needs of each child in order tocreate the expected environment and atmosphere for the learning processes. With the creation of shared responsibilities between students and teachers, a conducive learning situation is generated (Kusmoro, 2008).

It was deduced from the aforementioned statements that a healthy school environment contributes significantly to effective teaching and learning processes. The establishment of a conducive school environment makes all the students, academic and non-academic members perform their duties and roles optimally. Therefore a safe, comfortable, orderly school environment is a climate that arouses learning enthusiasm.

\section{Supporters of implementation of the 2013 curriculum}

The findings of the research conducted in the two schools based on interviews, documentation, and observations concerning the supporters of the Implementation of the 2013 Curriculum, it was generally deduced that the supporters of the implementation of State Senior High School 4 and 6 of Palangka Raya have many similarities. The supporters of the implementation of the 2013 Curriculum include the manual given during the socialization, directives from supervisors, school facilities, and 
LPMP. Teachers enforced this factor, by using a guidebook to develop various curriculum administrations, utilizing school facilities, participating in any socialization given by LPMP, and finding solutions to problems together with the principal. Assuming the principal and teachers were not able to determine a solution to the existing problem, the supervisor is called upon for assistance.

Principals and teachers always follow the 2013 Curriculum implementation training held by the LPMP. Teachers need to take advantage of school facilities such as the use of LCDs in the learning process in order for the students tobeexcited and also the surrounding environment needs to be utilizing as a source of learning. These learning facilities and resources need to be optimally utilized, maintained, and properly stored. During its development, teachers aside need to utilize the school premises as a more concrete learning source (Mulyasa, 2013).

\section{Obstacles of the implementation of 2013 cur- riculum}

The analysis of the study carried out in the two schools established from interviews, documentation, and observations concerning the obstacles in the implementation of the 2013 curriculum in State Senior High School 4 of Palangka Raya stated that teachers varying levels of ability was a hindering factor. Other obstacles encountered include a lack of infrastructure and funds to support the implementation of school programs. According to the statement of the Principal, the obstacles do not interfere with the implementation of the curriculum, and the learning process needs to be properly enforced. The obstacles encountered by teachers from the State Senior High School 6 of Palangka Raya was their inability to use IT, especially in searching for learning materials and resources on the internet. Another obstacle is the distance between the teacher's resident and school, which is located in Tangkiling.

Although the teachers atState Senior High School 6 of Palangka Raya have participated in various training, they need to attend training on manufacturing information technology- based learning tools. Currently, 90\% of teachers truly understand and implement learning with information technology. Therefore, it is expected that by next year, teachers who have understood and implemented Information Technology-based learning will reach $100 \%$. The learning process carried out by the teachers of State Senior High School 6 of Palangkaraya in the 2018/2019 school year stated that the attitude encountered during the activities were"receiving, conducting, respecting, appreciating, and practicing." Knowledge is gained through activities by"remembering, understanding, applying, analyzing, evaluating, and creating. Skills are obtained through activities such as observation, inquisitiveness, trying, reasoning, presenting, and creating.

Certain obstacles are encountered in developing a curriculum. The first lies in the teacher in their inability toparticipate in curriculum development. This is influenced by several elements such as 1) lack of time, 2) poor agreement between teachers, the principal, and administrator, 3) the teacher's ability, and 4) the community. For curriculum development, community support is needed both in funding and in providing feedback on the current educational system. The community is a source of input from schools, and its accuracy causes the school to be successful. Another obstacle faced by curriculum developers is the issue of cost, which is often expensive (Sukmadinata, 2012).

Considering the above findings, teachers are the spearhead of curriculum implementation, however, there are also limitations that tend to hinder the process of implementing the curriculum itself, some of the limitations include; teachers have limited time to evaluate information about innovation further, teachers have varying degrees of ability, understanding, and attitudes.The ability to implement curriculum innovations also varies due to lack of opportunity to improve their knowledge and skills, especially those related to curriculum innovation, and the attitude of one teacher to another towards embracing innovation (Arifin, 2013).

\section{Solutions in overcoming obstacles of imple- mentation of 2013 curriculum}

The findings of the study evaluated in the two schools regarding solutions on how to 
overcome obstacles in the implementation of the 2013 curriculum were adjusted by the inhibiting factors of each school's implementation. For the successful implementation of the 2013 curriculum, principals need to try to change the mindset of teachers so that they realize, understand, care, and have a high commitment towards its implementation. This change is in line with the development of science and technology.

Other efforts or measures by schools to improve the quality of teachers include assessment of pedagogy, personality, social, and professional competencies.

In addition, teachers do not only make lesson plans at the beginning of the year, but they also carry out continuous or routine learning so that when these materials are submitted, it does not contain the learning theme that was designed in the lesson plan. The scope of the material and the students' level of competency that needs to be met or achieved in an educational unit at a certain point and type are formulated in the Content Standards for each subject.

Efforts designed to overcome these problems are also needed byteachers to be able to effectively utilize the environment as a source of learning, which tends to make learning effective and facilitates the formation of core and basic competencies, as well as the achievement of learning objectives.

\section{Quality of Education}

Research evaluation obtained from the two schools regarding the academic achievement of State Senior High School 4 of Palangka Raya, proved that $100 \%$ of the students performed exceeding well in the 2018/2019 national exam. While at State Senior High School 6 of Palangkaraya, $100 \%$ of the students graduated in 2018/2019, however the quality of the school is not satisfying. Certain efforts were made by State Senior High School 4 of Palangka Raya to improve the quality of education in schools, one of the programs is entrepreneurship, through this program, many products such as the cultivation of oyster mushrooms, catfish, and suna called dayak onions has been produced. All the communities around State
Senior High School 4 of Palangka Raya, in collaboration with community stakeholders, are committed to implementing an internal quality assurance system for national education standards.

Efforts made to improve the quality of education at State Senior High School 6 of Palangka Raya stated that one of the programs is to collaborate with the Usaha Mulya Foundation, conducted by MoU (Memorandum of understanding) which is located in Tangkiling. Students and teachers were invited to practice socialization on creativity, computer training, and learning English using books, which aimed at simplifying the teaching and learning processes in the classroom.

The quality of education is not only determined by the school as a teaching institution, however, itis also regulated by the views and hopes of the community that tends to always change with times (Sagala, 2013).

Some characteristics of quality schools, include: continuously improving the standard of schools as a basic necessity, having monetary resources, in order to prevent damages that are very difficult to repair, the desire to achieve quality levels of leadership and admin staff to focus on efforts to prevent problems that tends to affect the principle of working properly both internally and externally. To manage poor incidents as feedback to achieve excellence and alter mistakes in order that attention to quality is an integral part of work culture. Carefully planning the standard of schools at the right time explains the roles and responsibilities of every individual. Creativity tends to generate quality and certain improvement processes which involve everyone in accordance with duties and obligations (Danim, 2002).

In formal academic regulations, both junior and senior secondary education organizes a branch or various branches of mathematics, technology, and certain branches, is expected to improve the quality of education, as well as strong commitment and motivation. Educators also have the commitment and hope that students need to perform exceptionally despite all the limitations of the teachers in the school, so that it increases the public confidence which is certainly thepride and hope of the school. 
All the previous discussionsare explained in

the following table.

Table 1: Cross site findings

\begin{tabular}{llll}
\hline \multirow{2}{*}{ Indicator } & \multicolumn{3}{c}{ Cross Site Findings } \\
\cline { 2 - 3 } & Site 1 & Site 2 \\
\hline
\end{tabular}

Implementation of optima

The learning process was adjusted to the 2013 curriculum, which is character-based. However, from the results of classroom learning observations, it was found that the creativity of the teacher was still not as expected.

Includes guidebooks provided during

Supporters of the implementation of the 2013 curriculum

Obstacles of the implementation of the 2013 curriculum

Solution to overcome obstacles in 2013 Curriculum Implementation

Providing opportunities for educators to take part in various training programs regularly

For graduation quality, it has met $100 \%$. Non-academic quality is good by participating in various activities and competitions.

facilities, and Educational Quality Assurance Agency (LPMP).

During the initial implementation of the 2013 curriculum at State Senior High School 4 of Palangka Raya, there were obstacles because teachers had varying degrees of ability.

Quality of Education 2013 Curriculum

The principal's leadership skill is optimal.

The learning process was adjusted to the 2013 curriculum, which is character-based. However, from the results of classroom observations, it was found that the teacher had not displayed optimal creativity.

Socialization provided by LPMP, direction from supervisors, on concepts of 2013 curriculum.
Teachers' lack the ability to use IT to search for learning materials and resources on the internet

School Principal's efforts to improve the quality of teachers, as well as establish cooperation between the school and parents of students

For graduation quality, it has met $100 \%$. Non-academic quality is good by participating in various activities and competitions.

\section{Conclusion and Recommendation}

a. The school has properly implemented K13, although it has not been effective.

b. The implemented K13, supports training and socialization provided by the Educational Quality Assurance Agency (LPMP), directives from supervisors, and the rules established by the Minister of Education and Culture. c. The obstacles are the teacher's inability to maximize the use of learning tools and infrastructure.

d. The principal and representative ability to provide a curriculum tailored to meet the obstacles experienced by schools and teachers need to be utilized in a pleasant and meaningful classroom atmosphere.

e. Achieve quality education, which encourages the school's progress. 
Recommended to:

a. Teachers are expected to create varieties of media and learning resources supported by technological devices.

b. The school principal and deputy head of curriculum are expected to foster teachers in developing learning tools.

c. The next researcher needs to be able to concisely develop more information relating to the 2013 curriculum in different sites and cases.

\section{Acknowledgment}

The authors are grateful to the Postgraduate Program of Educational Management, Universitas Lambung Mangkurat, Banjarmasin, for facilitating and supporting this research.

\section{References}

Andriyani, E., Ngadimun, \& Suriansyah, A. (2018). Character education management. IOSR Journal of research \& Method in Education (IOSR-JRME) , 8 (6), 13.

Arifin, \& Banawi. (2012). Etika dan profesi kependidikan. Yogyakarta: Ar-Ruzz Media.

Arifin, Z. (2013). Konsep dan model pengembangan kurikulum. Bandung: PT. Remaja Rosdakarya Offset.

Danim, S. (2002). Inovasi pendidikan dalam upaya meningkatkan profesionalisme tenaga kependidikan. Bandung: Pustaka Setia.

Hidayat, S. (2013). Pengembangan Kurikulum Baru. Bandung: PT. Remaja Rosdakarya.

Kusmoro. (2008). Pengaruh lingkungan terhadap efektivitas pembelajaran. Jakarta: PT. Kencana.

Metroyadi. (2017). Efforts to develop aspects of religious and moral values in differentiating good and bad actions using examples non examples with audio visual media variations in group B children in TK Aisyiyah Bustanul Athfal 31 Banjarmasin. Sagacious Jurnal Ilmiah Pendidikan dan Sosial, 4(1), 10-11.

Mulyasa. (2013). Pengembangan dan implementasi kurikulum 2013. Bandung: PT. Remaja Rosdakarya.

Mulyasa, E. (2017). Pengembangan dan implementasi kurikulum 2013. Bandung: PT. Remaja Rosdakarya.

Nasution. (2014). Asas-asas kurikulum. Jakarta: PT. Bumi Aksara. Sagala, S. (2013). Manajemen strategik dalam peningkatan mutu pendidikan. Bandung: Alfabeta.

Salasiah, Asniwati, \& Effendi, R. (2018). Character values in early childhood in the perspective of curriculum and parenting (Multi-site study in PAUD Islam Sabilal Muhtadin and PAUD Mawaddah, Banjarmasin Indonesia). European Journal of Education Studies , 5 (7), 41.

Suhaimi \& Rinawati. (2018). Management of character education curriculum, at Vocational High School 2 Kandangan. Advances in Social Science, Educational and Humanities Research, Volume 274, 273.

Suhaimi. (2018). Relationship between the role of the principal and attitudes towards the teaching profession with teacher work performance in Public High Schools in the Southern Hulu Sungai Regency. Jurnal Ilmiah Kependidikan , 13(5), pp.78-83.

Sukmadinata, N. S. (2012). Pengembangan kurikulum teori dan praktek. Bandung: PT. Remaja Rosdakarya.

Suriansyah, A. (2011). Pendidikan karakter dalam perspektif sistem pendidikan nasional. Paradigma, Jurnal Ilmu Pendidikan, 6 (11). pp. 117-130.

Suriansyah, A. (2015). Principal, teacher, parent and community leadership strategy in forming student character. Cakrawala Pendidikan, Th. XXXIV No. 2, 242.

Suryosubroto. (2010). Manajemen Pendidikan di Sekolah. Jakarta : Rineka Cipta. 